\title{
The Invisible Subordination of the Parsi Women: The Crow Eaters
}

\section{Kiranmai}

\author{
Sr. Assistant Professor, Aditya Engineering College, Surampalem, AP, India
}

\begin{abstract}
The paperthrows light on the myriads of Parsi culture and tradition.It explores the hypocrisy and double standards of the male patriarchy of Parsis society in The Crow Eaters. The paper conveys that several forms of the social system are both unjust and oppressive for women.Though the characters are drawn in the novel are perfectly fictitious, there are striking similarities with ordinary and real Parsi people rooted deeply into their age-old culture and tradition.
\end{abstract}

Keywords-Parsi, patriarchy, subordination, exploitation.

The Crow Eaters was the first novel published by famous Parsi writer Bapsi Sidhwa in the year 1978.The novel fulfills her profound desire to elevate the social apparatuses offered to the Parsi women. Sidwa discusses how different structures of male domination resulted in the invisible subordination of Parsi women. She elaborately portrays the suffering of the women characters at the hands of the Parsi partiarchial society.

Throughout the novel, it is observed that Jerbanoo craves for respect from her son-in-law Freddy but, her wish never gets fulfilled. She thinks that she has contributed immensely for the family and expects a return of the same from the family. During such occasions, Jerbanoo's daughter Putli is seen supporting her husband Freddy. Putli believes that it is the duty of the woman to tackle such situations: "It was the responsibility of a woman to convince their menfolk. Obviously, men become badtempered after exhausting labor and it is the minute thing that is significant" (73).

Simone de Beauviour states that a woman whether she is a wife, a daughter, a sister, a mother or a mother-inlaw is always considered inferior to man. Men always exploit or abuse women who are weak in physical attributes. In The Crow Eaters Freddy is seen abusing and exploiting Jerbanoo and attempts to murder her. He felt envious about her courageous activities. Simone de Beauvoir in The Second Sex states that women in all societies are considered weaker sex: "Woman is weaker than man" (Beauvoir 68).

While Putli could not stop herself walking behind her husband Freddy as per the Parsi customs. According to her a woman is inferior to man and she should never match her steps with man. She not only practice it herself but she also trains her daughters to do the same. But to her miseryYasmin, her daughter after getting married is seen to ignore the age-old Parsi customs and even questions the submissive attitude of the Parsi women.

In The Crow Eaters Sidhwa explores the hypocrisy and double standards of the male patriarchy of Parsis through Billy who wants his wife to be modern, wear modern clothes and communicate only in English but on the other hand, expects her to be the traditional Parsi wife at home who should come to him and serve him at his beck and call. In Way of Seeing John Berger observes the condition of women:

"A woman has to incessantly be careful... She has to survey everything she is and everything she does...Men act and women appear at...The evaluator of women in herself is male: the reviewed female. Thus she transforms herself into an entity and predominantly an entity of curiosity"(Berger 46-47).

When Yazdi desires to marry Rosy Watson, Freddy takes a very unusual and unnatural step to estrange his son, Yazdi, from his Indo-Anglican girlfriend. He further blames her to be a girl of loose character from Hira Mandi (a brothel). On hearing this Yazdi turned pale out of shock. Yazdi becomes abnormal due to shock. "The boy turned pale, and Freddy thought he would faint. He reached 
out a hand but Yazdi flinched like a lizard scarping against the wall'(157).

The problem of prostitution is also exposed in The Crow Eaters through the character of Rosy Watson. Owing to the force of her stepmother, Rosy was made to dance before men in Hira Mandi. The factors such as poverty, abduction, and the practice of Devadasi, etc shatteraway all the dream and aspirations of young girls who are forced into this nasty profession. The most shocking element of this problem is that in most of the cases the young girls are exploited by their own members of their families.

Rodabai is one more character trapped in the vicious setup of patriarchy. Her faith is similar to Putli. In her house, she has few rights which she could claim. Just like the Junglewallas in the family of Easymoneys also, man is the dictator of the family. Being the wife of a male chauvinist she is sanctioned to share his ruthless authority.

Tanya represents the young girls of the country who are deliberately kept uninformed about sex education. Tanya is a victim of carefully nurtured ignorance of sex education. Girls are intentionally kept ignorant on this subject. According to established norms of the society a girl should be a virgin physically as well as mentally until she gets married. Tanya gets married without having any knowledge of sex.

While the young boys are not barred from having knowledge of sex before marriage, Billy invites the girls of Hira Mandi three times before marriage to acquire the knowledge of sex. He reads Kama sutra and converses sex with his friends. This phenomenon leads to sexual domination of men over women. Acquiring sex education is an adventure for the man while it is considered a sin if a woman tries to do so.

Sidhwa makes her readers acquainted with the issue of gender bias among Parsis. The unwelcome gesture like rejection of the first born female child of Tanya is an example of gender bias. He refuses Rosy to be his daughter-in-law on the pretext of being a characterless girl. But Freddy who gets intimate with Rosy in Hira Mandi is considered as a nobleman in the community.

Tanya feels dejected and helpless towards her husband's greedy and domineering tendency regarding money. Tanya's individual, social and financial freedom was now at the feet of Billy. She tries all her best to cry a halt to his domineering male ego. Portraying the miserable condition of Tanya, Sidhwa states:

"Tanya was helpless against her
fascinating rival. Reacting like an abandoned mistress,she attacked his passion for her adversary, and he hated her forit.Theywere both raw with wounds. But Billy's determination andresolve were larger than Tanya's effort. Tanya finally gave into his tyrannies. For Tanya being an obedient wife was the only way to satisfy Billy"(SidhwaCrow275).

The female characters of the novel like Jerbanoo, Putli, Tanya, Yasmin and Rosy Watson are all trapped in the patriarchal ideology. She conveys that several forms of the social system are both unjust and oppressive for women. Sidhwa highlights on the aspect that women fortify themselves to confront the old traditions of exploitation of women to the backdrop of society to the extent of insufferable enslavement.

\section{REFERENCES}

[1] Sidhwa, Bapsi. The Crow Eaters. New Delhi: Penguin, 1990.

[2] Berger, John. Way of Seeing, Penguin publishers, 1972, pp.46-47.

[3] Beauvoir, Simone de. 1908-1986. The Second Sex. London : Jonathan Cape, 2009, pp. 24-503. 